Homepage: http://epubs.icar.org.in/ejournal/index.php/JWR

\title{
Development of high yielding bread wheat variety UAS 375 for timely sown, rainfed conditions of the Peninsular Zone of India
}

\author{
V Rudra Naik, SA Desai, Suma Biradar, MY Kamatar, SK Singh ${ }^{1 *}$, T Sudha and PV Patil \\ Sanjaya Rajaram Wheat Laboratory, University of Agricultural Sciences, Dharwad \\ ${ }^{1}$ ICAR-Indian Institute of Wheat and Barley Research, Karnal, India
}

\section{Article history}

Received: 14 May, 2018

Revised : 22 June, 2018

Accepted: 04 August, 2018

\section{Citation}

Naik VR, SA Desai, Suma Biradar, MY Kamatkar, SK Singh, T Sudha and PV Patil. 2018. Development of high yielding bread wheat variety UAS 375 for timely sown rainfed conditions of the Peninsular Zone of India. Wheat and Barley Research 10(2):102-107. doi. org/ 10.25174/2249-4065/2018/81917

\section{*Corresponding author}

Email: sksingh.dwr@gmail.com

(C) Society for Advancement of Wheat and Barley Research

\begin{abstract}
The bread wheat variety UAS 375 was released by Central Subcommittee on Crop Standards, Notification and Release of variety, Ministry of Agriculture, Govt. of India vide. S.O. 1379(E) dated: 27.03.2018 for cultivation in the Peninsular Zone of the country comprising states of Maharashtra and Karnataka. UAS 375 has recorded average yield of $21.4 \mathrm{q} / \mathrm{ha}$ with potential yield of $29.1 \mathrm{q} / \mathrm{ha}$. It has shown yield superiority of $14.4 \%$ over the best check variety NI 5439 (18.7q/ha) during three years of testing under timely sown, rainfed conditions. The variety UAS 375 has shown resistance to prevalent pathotypes of stem and leaf rusts in the target environments and has combination of $L r 13+1+$ and $S r 7 b+2+$ genes for diversified gene deployment against these rusts. It has better grain, product as well as nutritional quality parameters which makes it preferable variety for product developments. High yield potential of the variety UAS 375 under rainfed conditions coupled with disease resistance and quality traits makes it a suitable choice for the wheat growing farmers of the Peninsular India.
\end{abstract}

Keywords: Bread wheat, Peninsular Zone, rainfed crop, rust resistance.

\section{Introduction}

Wheat (Triticum aestivum $\mathrm{L}$ ) is one of the most important cereal crop grown in India for ensured food security. It is next to rice with respect to the production of 99.70 million tones (DAC\&FW, 2018) from an area of 29.72 Mha with productivity of $3354 \mathrm{~kg} /$ ha during $2017-18$. The recent climatic scenario posed a threat of reduction in food grains due to predicted increase in the frequency and severity of heat stress (Talukder et al., 2014). The diverse production conditions of wheat divided the country in 5 mega-zones of which Peninsular zone comprised the states of Maharashtra and Karnataka occupying an area of approx $1.10 \mathrm{mha}$. It is unique zone as all three wheat species namely bread wheat, durum wheat and dicoccum wheat are grown in this zone with the dominance of bread wheat. In this zone, wheat crop usually exposed to more heat as compared to other zones. Although there is availability of the irrigation water to wheat crop in the Peninsular Zone, a sizeable area of wheat crop depends on rains and gets 1-2 irrigations only. The major challenge in this zone is to sustain the wheat production under warmer climatic conditions and water scarcity. Therefore, the wheat improvement programme for this zone has a basic objective of improvement in thermo-tolerance to make genotypes adapted to water scarce conditions. (Mishra et al., 2014). Multilocational evaluation of the wheat genotype for yield stability under stress conditions is a classic approach towards identification of superior genotypes for such environments (Rane et al., 2007). The research efforts in this zone have enabled to release wheat varieties NI 5439 and NIAW 1415 for these conditions which are released in 1973 and 2011, respectively. As these are very old cultivars and therefore, there is need to develop new cultivars suitable to present climatic conditions. Keeping in view these concerns, development of high yielding wheat cultivars for rainfed/limited irrigation conditions was taken under AICRP on Wheat \& Barley at University 
of Agricultural Sciences (UAS), Dharwad. The research efforts led to development of wheat variety UAS 375 which was released and notified by the Central Sub-committee on Crop Standards, Notification and Release of Varieties for Agricultural crops (CVRC) vide S.O. 1379(E) dated $27^{\text {th }}$ March, 2018 for timely sown rainfed conditions of the Peninsular zone.

\section{Materials and methods}

The bread wheat variety UAS 375 was developed from the cross UAS320/GW322//LOK62 at UAS, Dharwad following pedigree method (Fig. 1). In its course of development, the segregating material was evaluated under both irrigated and rainfed conditions. This helped in identification of genotype having high yield levels and adaptability to water stress conditions. After getting uniformity, it was evaluated in yield trials conducted at Annigeri and Dharwad in 6 rowed plot of $6.0 \mathrm{~m}$ length spaced at $20 \mathrm{~cm}$ under rainfed condition alongwith check varieties NIAW 1415 and NI 5439, the released and commercialized varieties in the zone for timely sown rainfed conditions. Based on its performance, it was contributed to NIVT 5A-Rainfed trial under AICRP

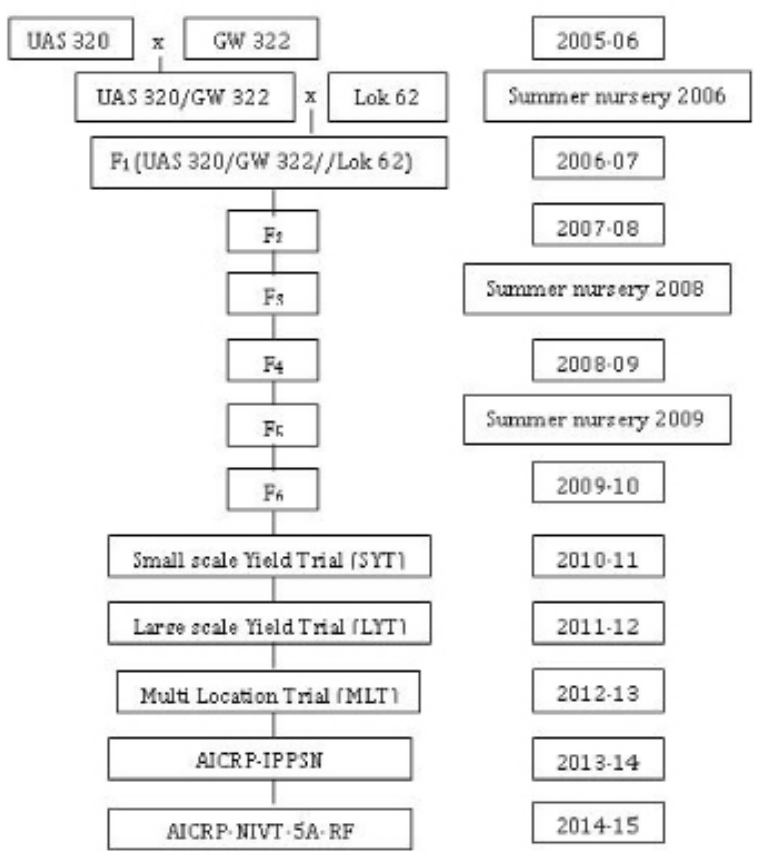

Fig.1: Scheme for development of wheat variety UAS 375

on Wheat \& Barley during 2014-15 in which evaluation was done in 6 rowed plot of $6.0 \mathrm{~m}$ length spaced at $20 \mathrm{~cm}$ alongwith zonal check NI 5439 in an alpha lattice design. Afterward it was promoted to Advanced Varietal Trials of the Peninsular zone for multilocational evaluation in a randomized block design with 4 replications in 12 rowed plot of $6.0 \mathrm{~m}$ length spaced at $20 \mathrm{~cm}$. The recommended package of practices was adopted to raise a satisfactory crop as per AICRP-W\&B standards. During the course of the coordinated evaluation, data on yield, ancillary traits, disease resistance, quality attributes and agronomical manipulations were recorded. The entry was also characterized for different DUS traits as per the standard procedures (PPV\&FRA, 2007) for varietal identification.

\section{Result and discussion}

Yield evaluation under coordinated trials: The performance of UAS 375 was assessed in the multilocational station trials during 2012-13 at Annigeri and Dharwad where it recorded average yield of $2521 \mathrm{~g}$ per plot equivalent to $35.0 \mathrm{q} /$ ha which was $44.5 \%$ higher than the best check variety NI 5439 (Table 1). It was earlier in heading and maturity than the recent check variety NIAW 1415 . The disease reactions were recorded under natural conditions at both the locations in which it showed non appearance of disease in UAS 375 as well as in check varieties.

Table 1: Performance of UAS 375 in multilocational station trial

\begin{tabular}{ccccc}
\hline \multirow{4}{*}{ Parameters } & UAS- & NIAW & NI-5439 & CD \\
& BW-10048 & at \\
& (UAS 375) & 1415 (C) & (C) & $5 \%$ \\
\hline
\end{tabular}

Yield performance $\mathrm{In} \mathrm{Kg} / \mathrm{ha}$

$\begin{array}{lllll}\text { Anigeri } & 1818 & 1522 & 1643 & 439 \\ \text { Dharwad } & 3224 & 1621 & 1847 & 418 \\ \text { Mean } & 2521 & 1572 & 1745 & \\ \begin{array}{l}\text { \% increase } \\ \text { over }\end{array} & & 60.4 & 44.5 & \end{array}$

Agronomic traits

$\begin{array}{lccc}\begin{array}{l}\text { Days to } \\ \text { heading }\end{array} & 48 & 61 & 48 \\ \begin{array}{l}\text { Days to } \\ \text { maturity }\end{array} & 90 & 107 & 90 \\ \begin{array}{l}\text { Colour } \\ \text { Texture }\end{array} & \text { White } & \text { Amber } & \text { Amber } \\ \begin{array}{l}\text { 1000-grains } \\ \text { weight (g) }\end{array} & 36.1 & \begin{array}{c}\text { Semi } \\ \text { hard }\end{array} & \begin{array}{c}\text { Semi } \\ \text { hard }\end{array} \\ \end{array}$

Disease data under natural conditions

\begin{tabular}{lccc} 
Stem rust & 0 & 0 & 0 \\
Leaf rust & 0 & 0 & 0 \\
Leaf blight & 12 & 0 & 1 \\
\hline
\end{tabular}


Based on yield performance and disease resistance, it was promoted for multilocational coordinated evaluation under AICRP on Wheat \& Barley in trial NIVT 5A-RF during 2014-15. The results indicated that it has significant yield superiority over NI 5439 and thereafter promoted for evaluation in Advanced Varietal Trials under rainfed conditions in the Peninsular Zone during 2015-16 and 2016-17. Variety UAS 375 had an average yield of $21.4 \mathrm{q} /$ ha and had shown $14.4 \%$ yield superiority over the best check variety NI $5439(18.7 \mathrm{q} / \mathrm{ha})$ over three years of testing under coordinated trials (Table 2). It showed higher yield potential of $29.1 \mathrm{q} / \mathrm{ha}$ compared to NI $5439(25.7 \mathrm{q} / \mathrm{ha})$ and NIAW 1415 (24.4q/ha). It has shown superior performance across the zone by appearing 8 times out of 9 in $1^{\text {st }}$ nonsignificant group as compared to the check variety NI 5439 (Anonymous, 2015, 2016, 2017a). UAS 375 also had earlier heading ad maturity alongwith comparatively taller plants with bolder seeds under rainfed conditions. The DUS characterization indicated semi-erect growth habit, dark green foliage, drooping flag leaf with strong sheath waxiness, medium dense waxy ears, appressed white awns, elliptical shape grains with medium crease and very short brush hair length (Table.2).

Table 2. Performance of wheat variety UAS 375 over check variety for grain yield, ancillary and DUS traits during 2014-15 to 2016-17

\begin{tabular}{|c|c|c|c|c|c|c|}
\hline \multirow{2}{*}{ Trials } & \multirow{2}{*}{ Locations } & \multirow{2}{*}{ Trials } & \multirow{2}{*}{$\begin{array}{c}\text { Variety } \\
\text { UAS } 375\end{array}$} & \multicolumn{2}{|c|}{ Check varieties } & \multirow{2}{*}{$\begin{array}{c}\mathrm{CD} \\
(0.05)\end{array}$} \\
\hline & & & & NI 5439 & NIAW 1415 & \\
\hline \multicolumn{7}{|c|}{ Yield performance } \\
\hline NIVT-5A-RF & Annigeri, Dharwad & 2 & 27.7 & 22 & - & 4.1 \\
\hline AVT I-RF-PZ & $\begin{array}{l}\text { Bagalkot, Dharwad, } \\
\text { Vijayapur }\end{array}$ & 3 & 17.2 & 14.2 & 12.9 & 1.6 \\
\hline \multirow[t]{2}{*}{ AVT II-RF-PZ } & $\begin{array}{l}\text { Jalgaon, Bagalkot, } \\
\text { Vijayapur, Bailhongal }\end{array}$ & 4 & 21.4 & 20.4 & 20.9 & 2.3 \\
\hline & Weighted mean & & 21.4 & 18.7 & 17.5 & \\
\hline \multicolumn{3}{|c|}{$\%$ Increase over checks based on weighted mean } & - & 14.4 & 22.3 & \\
\hline \multicolumn{3}{|c|}{ Frequency in 1 st $\mathrm{NS}$ group } & 9-Aug & 9-Apr & 7-Apr & \\
\hline \multicolumn{3}{|c|}{ Yield potential (q/ha) } & 29.1 & 25.7 & 24.4 & \\
\hline \multicolumn{7}{|l|}{ Ancillary traits } \\
\hline \multicolumn{3}{|l|}{ Days to heading } & 54 & 58 & 58 & \\
\hline \multicolumn{3}{|l|}{ Days to maturity } & 103 & 104 & 108 & \\
\hline \multicolumn{3}{|c|}{ Plant height $(\mathrm{cm})$} & 61 & 61 & 55 & \\
\hline \multicolumn{3}{|c|}{ 1000-grain weight $(\mathrm{g})$} & 39 & 39 & 37 & \\
\hline \multicolumn{7}{|l|}{ DUS traits } \\
\hline \multicolumn{3}{|l|}{ Growth habit } & Semi erect & Erect & Semi erect & \\
\hline \multicolumn{3}{|c|}{ Coleoptile (Anthocyanin pigmentation) } & Absent & Present & Absent & \\
\hline \multicolumn{3}{|c|}{ Foliage colour (Boot stage) } & Dark green & Pale green & Green & \\
\hline \multicolumn{3}{|c|}{ Flag leaf: Attitude } & Drooping & Semi erect & Semi erect & \\
\hline \multicolumn{3}{|c|}{ Flag leaf: Hairs on auricles } & Absent & Present & Absent & \\
\hline \multicolumn{3}{|c|}{ Flag leaf: Waxiness of sheath } & Strong & Medium & Medium & \\
\hline \multicolumn{3}{|l|}{ Ear Waxiness } & Medium & Weak & Weak & \\
\hline \multicolumn{3}{|l|}{ Ear Density } & Medium & Dense & Lax & \\
\hline \multicolumn{3}{|l|}{ Awn Attitude } & Appressed & Medium & Spreading & \\
\hline \multicolumn{3}{|l|}{ Grain Shape } & Elliptical & Oblong & Oblong & \\
\hline \multicolumn{3}{|l|}{ Grain Crease } & Medium & Deep & Shallow & \\
\hline \multicolumn{3}{|c|}{ Grain Brush hair length } & Very short & Medium & Short & \\
\hline
\end{tabular}


The molecular profiling of UAS 375 and check varieties was done using STS/AS-PCR markers that indicated presence of Rhtb, VP1B3A, Wxb1A, Vrn-1a, Ppd-D1 (228),
PPO33 (290) and DuPw004b genes in UAS 375 as shown in table.3.

Table 3: Profile of the gene distribution using STS/AS-PCR markers

\begin{tabular}{|c|c|c|c|c|c|c|c|c|c|c|c|c|c|}
\hline \multirow{3}{*}{ Genotypes } & \multicolumn{13}{|c|}{ Genes } \\
\hline & \multirow{2}{*}{$R h t b$} & \multirow{2}{*}{$V p 1 B 3 a$} & \multirow{2}{*}{$W x b 1 A$} & \multicolumn{2}{|c|}{ DuPw004 } & \multicolumn{2}{|c|}{$P p d-D 1$} & \multicolumn{2}{|c|}{ РРО33 } & \multirow{2}{*}{$\operatorname{Lr} 10$} & \multirow{2}{*}{$\operatorname{Lr} 34$} & \multirow{2}{*}{ VrnA1a } & \multirow{2}{*}{$\begin{array}{l}\text { Vrn- } \\
\text { A1bR1 }\end{array}$} \\
\hline & & & & $A$ & $B$ & 228 & 414 & 290 & 481 & & & & \\
\hline UAS 375 & + & + & + & - & + & + & - & + & - & - & - & + & - \\
\hline NI 5439 (C) & - & + & + & - & + & - & + & + & - & + & + & + & + \\
\hline NIAW 1415 (C) & + & + & + & + & - & + & - & + & + & - & + & - & + \\
\hline
\end{tabular}

+ denotes presence and - denotes absence of amplification

Evaluation in agronomical trials for variable nitrogen levels: UAS 375 was evaluated for agronomical manipulations during 2016-17 at different nitrogen levels $(40 \mathrm{~kg}, 60 \mathrm{~kg}$, $80 \mathrm{~kg}$ per ha) at Dharwad, Pune and Washim. The results indicated (Table 4) that UAS 375 was highest yielding variety at all the nitrogen levels with mean yield of 17.3q/ ha which is $4.2 \%$ higher than the best check NI 5439 (16.6q/ha). This higher yield of UAS 375 was attributed to high grain number per spike (24.0) coupled with bolder grains (37g TGW) as compared to the check varieties (Anonymous 2017b).

Table 4: Evaluation for agronomical manipulations at different nitrogen levels

\begin{tabular}{llcccl}
\hline Traits & $\begin{array}{l}\text { Nitrogen } \\
\text { levels }\end{array}$ & UAS 375 & NI 5439 (C) & NIAW 1415(C) & $\begin{array}{l}\text { Critical difference } \\
\text { (5\% level) }\end{array}$ \\
\hline Yield (q/ha) & N1 (40kg/ha) & 15.4 & 14.6 & 13.9 & $\begin{array}{l}\text { Nitrogen }(\mathrm{A})=1.27, \\
\text { Variety }(\mathrm{B})=1.09,\end{array}$ \\
& N2 (60kg/ha) & 17.6 & 17.4 & 15.5 & B within A NS, \\
& N3 (80kg/ha) & 19 & 18 & 17.5 & A within B $=$ NS \\
& Mean & 17.3 & 16.6 & 15.6 & \\
Spike number /m2 & Mean & 204 & 252 & 233 & Variety $=8.63$ \\
Grains per spike & Mean & 23.98 & 19.48 & 18.62 & Variety $=1.49$ \\
1000-Gr Wt. (g) & Mean & 36.85 & 34.76 & 36.38 & Variety $=0.5$ \\
\hline
\end{tabular}

Disease resistance: Bread wheat cultivar UAS 375 was evaluated for resistance to diseases especially rust and leaf blight under natural as well as artificially created epiphytotic conditions under AICRP-W\&B. During the period under evaluation, there was no rust development at any of the centre in the zone under natural condition. Under artificial epiphytotic conditions, stem (black) as well as leaf (brown) rusts were created that showed resistance in wheat variety UAS 375 . The gene postulation indicated presence of $\operatorname{Lr} 13+1+, S r 7 b+2+$ genes which are different to those in popular cultivars NI $5439(\operatorname{Lr} 34+, S r 11+)$ and NIAW $1415(\operatorname{Lr} 26+1+, S r 31+2+)$ which will be beneficial for diversified deployment of rust resistant genes (Table.5).

The seedling resistance test (SRT) was also done at IIWBR Regional centre, Flowerdale, Shimla and RWRRS, Mahabaleshwar against prevalent pathotypes which indicated resistance reaction in UAS 375 against most of
Table 5: Disease reaction and gene postulation

\begin{tabular}{lccc}
\hline Disease & UAS 375 & $\begin{array}{c}\text { NI 5439 } \\
(\mathrm{C})\end{array}$ & $\begin{array}{c}\text { NIAW 1415 } \\
(\mathrm{C})\end{array}$ \\
\hline Rust Diseases & HS (ACI) & HS (ACI) & HS (ACI) \\
Brown (Leaf) Rust & $40 \mathrm{~S}(13.4)$ & $80 \mathrm{~S}(39.2)$ & $20 \mathrm{~S}(3.3)$ \\
Black (Stem) Rust & $40 \mathrm{~S}(8.7)$ & $80 \mathrm{~S}(29.3)$ & $30 \mathrm{MS}(3.6)$ \\
Lr gene & $13+1+$ & $34+$ & $26+1+$ \\
Sr gene & $7 b+2+$ & $11+$ & $31+2+$ \\
Other diseases & HS (Av) & HS (Av) & HS (Av) \\
Karnal Bunt & $14.7(8.1)$ & $26.3(15.5)$ & $24.8(12.5)$ \\
Leaf blight (dd) & $89(58)$ & $99(67)$ & $89(67)$ \\
Powdery mildew (0-9) & $7(5)$ & $8(4)$ & $8(5)$ \\
\hline
\end{tabular}

$H S$ - Highest score, ACI- Av coefficient of infection, Av-Average score 
the pathotypes as compared to check varieties (Table.6). The variety UAS 375 showed better resistance to Karnal bunt, leaf blight and powdery mildew as compared to check varieties as shown in table 5 (Anonymous, 2015b, 2016b, 2017c).

Table 6: Seedling Resistance test for prevalent rust pathotypes

\begin{tabular}{lcccccc}
\hline \multirow{2}{*}{ Pathotypes } & \multicolumn{5}{c}{ Shimla } & \multicolumn{3}{c}{ Mahabaleshwar } \\
\cline { 2 - 7 } Leaf rust & UAS 375 & NI5439 (C) & NIAW $1415(\mathrm{C})$ & UAS 375 & NI5439 (C) & NIAW 1415 (C) \\
2-Dec & $\mathrm{R}$ & $\mathrm{S}$ & $\mathrm{R}$ & $\mathrm{S}$ & $\mathrm{S}$ & $\mathrm{R}$ \\
5 -Dec & $\mathrm{R}$ & $\mathrm{MS}$ & $\mathrm{R}$ & $\mathrm{R}$ & $\mathrm{S}$ & $\mathrm{R}$ \\
$77-2$ & $\mathrm{R}$ & $\mathrm{S}$ & $\mathrm{R}$ & $\mathrm{S}$ & $\mathrm{S}$ & $\mathrm{R}$ \\
$77-5$ & $\mathrm{R}$ & $\mathrm{S}$ & $\mathrm{R}$ & $\mathrm{S}$ & $\mathrm{S}$ & $\mathrm{R}$ \\
$77-9$ & $\mathrm{R}$ & $\mathrm{R}$ & $\mathrm{R}$ & $\mathrm{NG}$ & $\mathrm{S}$ & $\mathrm{R}$ \\
$104-2$ & $\mathrm{R}$ & $\mathrm{R}$ & $\mathrm{R}$ & $\mathrm{S}$ & $\mathrm{S}$ & $\mathrm{R}$ \\
Stem rust & & & & & & \\
11 & $\mathrm{R}$ & $\mathrm{S}$ & $\mathrm{R}$ & $\mathrm{R}$ & $\mathrm{S}$ & $\mathrm{R}$ \\
$40-\mathrm{A}$ & $\mathrm{R}$ & $\mathrm{S}$ & $\mathrm{R}$ & $\mathrm{R}$ & $\mathrm{S}$ & $\mathrm{R}$ \\
42 & - & - & - & $\mathrm{R}$ & $\mathrm{R}$ & $\mathrm{R}$ \\
$117-6$ & $\mathrm{R}$ & $\mathrm{R}$ & $\mathrm{R}$ & $\mathrm{R}$ & $\mathrm{R}$ & $\mathrm{R}$ \\
122 & $\mathrm{R}$ & $\mathrm{R}$ & $\mathrm{R}$ & $\mathrm{R}$ & $\mathrm{R}$ & $\mathrm{R}$ \\
\hline
\end{tabular}

R-Resistant, $S$-susceptible, NG-not germinated

Quality traits: Wheat variety UAS 375 was evaluated for different grain, processing and nutritional quality parameters as per the AICRP on Wheat \& Barley protocol. UAS 375 has shown better performance for various grain and product quality parameters, i.e., grain hardness index, HMW Glu 1 score, bread quality, extraction rate, biscuit diameter and spread factor (Table.7) which indicated its better suitability for industrial processing and product making traits. It possesses higher values for other quality traits like protein content $(13.8 \%)$, hectoliter weight $(80.3 \mathrm{~kg} / \mathrm{hl})$, grain appearance score (6.3), chapatti quality (7.8) and bread loaf volume $(588 \mathrm{ml})$ that fall in category of better quality as per the grain quality standards (Anonymous, 2016c, 2017d).
Table 7: Quality attributes in UAS 375 and check varieties under coordinated testing

\begin{tabular}{lccc}
\hline Quality parameters & UAS 375 & $\begin{array}{c}\text { NI 5439 } \\
\text { (C) }\end{array}$ & $\begin{array}{c}\text { NIAW 1415 } \\
(\mathrm{C})\end{array}$ \\
\hline Protein (\%) & 13.8 & 14.5 & 14.3 \\
Grain appearance (max score 10) & 6.3 & 6.4 & 6.4 \\
Hectolitre weight (kg/hl) & 80.3 & 79.8 & 80.7 \\
Sedimentation value (ml) & 47 & 54 & 52 \\
Grain Hardness index & 87 & 80 & 85 \\
HMW Glu-1 Score & 8 & 6 & 7 \\
Chapatti quality (max score 10) & 7.8 & 7.8 & 8.1 \\
Bread loaf volume (ml) & 588 & 588 & 583 \\
Bread quality (max score 10) & 7.4 & 7.4 & 7.3 \\
Extraction rate (\%) & 73.5 & 71.3 & 73 \\
Biscuit diameter (cm) & 7.09 & 6.57 & 6.67 \\
Biscuit Spread factor & 5.86 & 5.23 & 5.79 \\
\hline
\end{tabular}

\section{Conclusion}

The research efforts led to development of wheat variety UAS 375 which was released and notified by the Central Sub-committee on Crop Standards, Notification and
Release of Varieties for Agricultural crops (CVRC) vide S.O. 1379(E) dated 27th March, 2018 for timely sown rainfed conditions of the Peninsular Zone. From the 
above results, it has been indicated that the wheat variety UAS 375 has high yield levels under rainfed condition coupled with better disease resistance and quality traits. This variety may provide a good choice to the farmers of Maharashtra and Karnataka for harvesting higher wheat yields under low input and stressed production conditions.

\section{Acknowledgement}

The article is based on the variety release proposal of UAS 375 submitted to the CVRC and the authors acknowledge the support of cooperators in Peninsular Zone under the AICRP on Wheat \& Barley.

\section{References}

1. Anonymous, 2015a. Results of the All India Coordinated Research Project on Wheat \& Barley, 2014-15, Crop Improvement, Vol.I, ICAR-IIWBR, Karnal. pp282.

2. Anonymous, 2015b. Results of the All India Coordinated Research Project on Wheat \& Barley, 2014-15, Crop Protection, Vol.III, ICAR-IIWBR, Karnal. pp269.

3. Anonymous, 2016a. Results of the All India Coordinated Research Project on Wheat \& Barley, 2015-16, Crop Improvement, Vol.I, ICAR-IIWBR, Karnal. pp258.

4. Anonymous, 2016b. Results of the All India Coordinated Research Project on Wheat \& Barley, 2015-16, Crop Protection, Vol.III, ICAR-IIWBR, Karnal. pp221.

5. Anonymous, 2016c. Results of the All India Coordinated Research Project on Wheat \& Barley, 2015-16, Quality, Vol. IV, ICAR-IIWBR, Karnal. pp226.

6. Anonymous, 2017a. Results of the All India Coordinated Research Project on Wheat \& Barley, 2016-17, Crop Improvement, ICAR-IIWBR, Karnal. pp249.
7. Anonymous, 2017b. Results of the All India Coordinated Research Project on Wheat \& Barley, 2016-17, Crop Protection, ICAR-IIWBR, Karnal. pp200.

8. Anonymous, 2017c. Results of the All India Coordinated Research Project on Wheat \& Barley, 2016-17, Resource Management, ICAR-IIWBR, Karnal. Pp168.

9. Anonymous, 2017d. Results of the All India Coordinated Research Project on Wheat \& Barley, 2016-17, Quality, ICAR-IIWBR, Karnal. Pp176.

10. DAC\&FW. 2018. $4^{\text {th }}$ Advance Estimates of production of major crops for 2017-18., Press Information Bureau, Ministry of Agriculture \& Farmers Welfare, Government of India, 29 August 2018.

11. Mishra SC, SK Singh, Ravindra Patil, Nabin Bhusal, Arvind Malik and Sindhu Sareen. 2014. Breeding for heat tolerance in Wheat. In: Recent trends on production strategies of wheat in India (Eds. RS Shukla, PC Mishra, R Chatrath, RK Gupta, SS Tomar and Indu Sharma). JNKVV, Jabalpur \& ICAR-IIWBR, Karnal, Pp. 15-29.

12. PPV\&FRA. 2007. Guidelines for the conduct of test for distinctiveness, uniformity and stability on bread wheat (Triticum aestivum L.), PPV\&FR Authority, GOI, New Delhi, Pp. 17.

13. Rane J, RK Pannu, VS Sohu, RS Saini, B Mishra, J Shoran, J Crossa, M Vargas and AK Joshi. 2007. Performance of yield and stability of advanced wheat genotypes under heat stress environments of the IndoGangetic Plains. Crop Science. 47:1561-1573

14. Talukder ASMHM, Glenn K McDonald and Gurjeet S Gill. 2014. Effect of short-term heat stress prior to flowering and early grain set on the grain yield of wheat. Field Crops Research, 160:54-63. 